\section{FINDS AND ENVIRONMENTAL EVIDENCE}

The finds assemblage from Thainstone predominantly comprised pottery from the urned cremation burials, the pit group, Feature Group 1 and Structure 2, and stone tools from the pit group and souterrain. Isolated finds such as samian ware and glass were also identified from Structure 2. Vitrified material was identified, which indicated that metalworking had occurred within the area or in the proximity. Additionally, charcoal and plant remains were also recovered from samples. All artefactual and environmental materials were analysed by specialists, with the results adding to the overall understanding of the site, including potential contemporaneity of features and structures.

\subsection{Pottery}

At least 19 vessels were represented in the pottery assemblage, with the most intact from the cremation burials and Pit 091. In comparison, the pottery from Structure 2 and the souterrain were more fragmentary. Unstratified pottery has been omitted and will not be discussed further.

The inverted cremation urns (Vessels 2-5; Table 2) were all undecorated bucket-shaped urns commonly associated with the Middle to Late Bronze Age (Illus $18 \mathrm{a}-\mathrm{c}$ ). Vessels 3-5 were made of a fine clay with frequent, large, angular grits measuring up to $5 \mathrm{~mm}$, and had a micaceous surface. Vessel 2 was made of a similar fabric but had occasional, rounded grey grits of up to $2 \mathrm{~mm}$. Rim diameters varied from $130 \mathrm{~mm}$ to $160 \mathrm{~mm}$ and had a wall thickness between $10 \mathrm{~mm}$ and $15 \mathrm{~mm}$. The rims were flat, some with rounded corners, and Vessel 5 was internally bevelled. Vessel 4 had two perforations close to the rim on one side, possibly from an attempt to repair it. A similar vessel was found at Kintore, Aberdeenshire (MacSween 2008: 188). Vessels 3 and 4 had burnt residue on their interior surface, indicating they had been
A

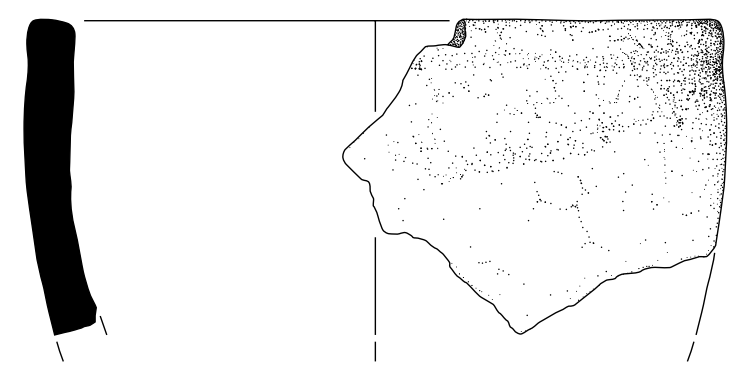

B

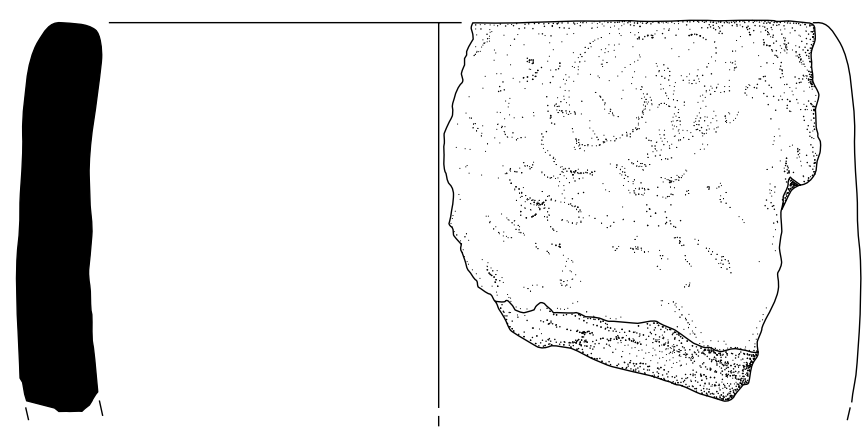

C
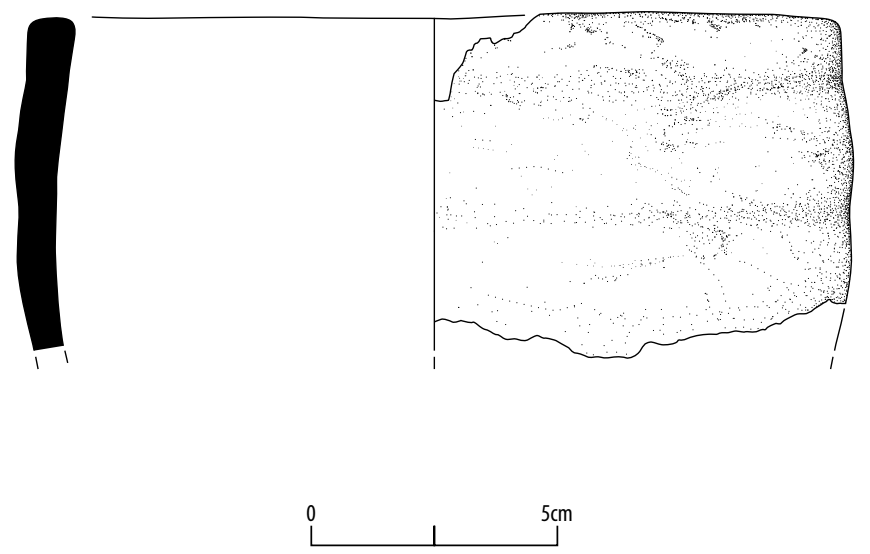

Illus 18 Vessels associated with cremation burials: A Vessel 2, Cremation Pit 094; B Vessel 3 , Cremation Pit 097; C Vessel 4, Cremation Pit 126 
used domestically prior to being used as funerary urns. All the vessels were constructed using angled straps, with Vessel 4's straps being narrower and more prominent. The surfaces were smoothed with a wet hand or cloth prior to firing. The uniformity in colour across the pots indicated close control of the temperature within the kiln, resulting in an even firing.

Two vessels were also present in the pit group in the south-east of Area A: Vessel 1 from Pit 091 (Illus 19) and Vessel 6 from Pit 067. Vessel 1 was a plain, jar-shaped urn with a flat base and vertical sides which tapered slightly to a relatively flat rim and had a wall thickness between $11 \mathrm{~mm}$ and $13 \mathrm{~mm}$. It was similar to Vessels 2-5 in form and fabric and had also been constructed using angled straps. Unlike the urns in Pits 094, 097, 126 and 129, Vessel 1 was upright and had a stone lid. Vessel 6 from Pit 067 contained fragments of a robust, large jar-shaped vessel, constructed of a similar clay to the cremation urns in Area A. Residue was present on the interior surface, indicating that the vessel was used domestically, like Vessels 3 and 4. Additionally, fragments of three vessels (17-19) were also located within Feature Group 1. Feature 017 contained a rim sherd from a slightly inverted, fine clay vessel (Vessel 17) and a body sherd from a robust vessel with a raised, rounded ridge, possibly from a cordon or a crude strap joint (Vessel 18). Vessel 19 was characterised by a featureless wall sherd and was
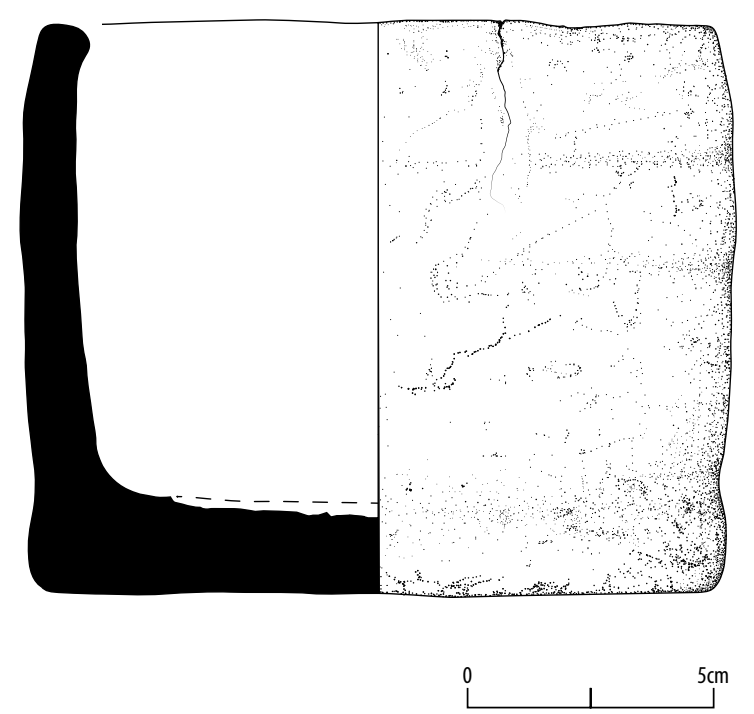

Illus 19 Vessel 1, Pit 091 recovered from Feature 005. Vessel 17 was probably a bucket urn and was similar to the cremation vessels in Area A.

Undecorated jar- or bucket-shaped urns are a widely known form, falling within the 'bucket urn' category or its domestic equivalent, 'flat-rimmed ware'. It is now generally accepted these terms do not describe a coherent group and are likely to mask subtle chronological and local variations which are yet to be fully explored (Bradley \& Sheridan 2005: 275; Halliday 1988: 108; Sheridan 2003: 211). However, while earlier studies placed bucket urns anywhere between the 3rd and 1 st millennia BC (Coles \& Taylor 1970: 97-8), the re-dating of urns from stone circles has reduced this range and a date between the mid-2nd millennium $\mathrm{BC}$ and around $800 \mathrm{BC}$ is now most likely (Bradley \& Sheridan 2005: 227-8; Sheridan 2015: 146). Parallels for these urns are therefore widespread, for example in Middle Bronze Age contexts at Meadowend Farm, Clackmannanshire (Sheridan 2018: 287-8), Late Bronze Age and Iron Age deposits in Sculptor's Cave, Covesea (Cruickshanks \& Sheridan forthcoming) and at Iron Age Meare Lake Village in Somerset (Bulleid \& Gray 1948: 48). More locally, two very similar urns were found in Middle to Late Bronze Age cremation pits at Kintore, Aberdeenshire, one of which has a double perforation near the rim (MacSween 2008: 188). Similar pots were also found in Bronze Age roundhouses at Drumyocher, Aberdeenshire (Johnson 2017: illus 18), showing the difficulties in assigning function from form alone.

The pottery assemblage from Structure 2, the souterrain and the Feature Group was less coherent than that from the cremation features, as most vessels were represented by a single rim or undiagnostic body sherds. Vessels 7 (Illus 20a), 8, $9,10,12,13,14$ and 15 were recovered from the curvilinear ditches and Vessel 16 (Illus 20b) was within a post hole in Structure 2. The most notable was Vessel 7: a vessel with gently everted rim, fine wall and decorative line of fingernail impressions along the rim and a diameter of 180-200mm. Vessel 8 had an unusual internally lipped rim and Vessels 9-10 and 13-15 were variations on the flat-rimmed ware group. Vessels 12 and 16 were plain, rounded forms. Many of the sherds were notably abraded and some features or spreads, especially within Structure 2 , produced single sherds from several different 
vessels, all suggesting midden-like material which had been moved around over time. The majority of the pottery from Structure 2 could only be broadly dated as 'late prehistoric', with only Vessel 7 being confidently dated to the Iron Age.

The souterrain and other isolated features are summarised together as no distinctive vessels were noted. All sherds from these features could conceivably belong to other vessels discussed above. A total of 34 sherds were recovered from these features, with small clusters of eight sherds from Pit 217 (part of the souterrain) and six each from Pit 027 and Ditch 030 and five from Pit 028 (all part of the pit group). The sherds display a range of wallthicknesses, fabrics, surface abrasion and colour, illustrating a very mixed, dispersed assemblage, as with that from Structure 2, and are therefore potentially broadly contemporary.

The Iron Age pottery sequence in north-east Scotland is still poorly understood. Assemblages tend to be small and it seems ceramic vessels were not commonly used in this area during the Iron Age compared to preceding periods or in some other areas, for example the Western Isles. Even on sites which have seen large-scale excavation, such as at Birnie, Culduthel and Kintore (MacSween in prep; 2008; 2020), a significant proportion of the pottery assemblages tend to derive from early prehistoric activity at the same site. The only vessel from Thainstone to have firm Iron Age parallels was Vessel 7, with everted rim, relatively thin walls and fingernail decoration. For example, two pots of similar everted-rim form and fabric to Vessel 7 were discovered at Birnie, Moray, which contained hoards of late 2nd-century AD Roman denarii (Holmes 2006: 3). Examples have also been recovered from Redcastle souterrain, Angus, dating to the first few centuries AD (McGill 2005: 79) and from Dunnicaer promontory fort, dating to between the $2 \mathrm{nd}$ and 4th centuries AD (Cruickshanks forthcoming). However, none of those vessels were decorated and the fingernail-impressed rim is difficult to parallel in this area. Fingernail-impressed decoration was widely employed on pottery in the Western Isles during the Iron Age, for example at the Iron Age wheelhouse at Cnip on Lewis (MacSween 2006: 98). Dating the pottery assemblage from Structure B is therefore problematic, as Iron Age assemblages are poorly understood in the area and with the ubiquity of 'flat-rimmed ware', it is not unreasonable to suspect this type of vessel would have continued into the Iron Age.

\subsection{Samian ware}

A single sherd of Roman pottery was recovered from the central spread, 161, of Structure 2 (Illus 21). It was the rim sherd from a central Gaulish samian-ware vessel (form 37) of a 2 nd century AD date. Heavy post-depositional wear impeded the assessment of its condition, but there was no certain evidence that it had been reused (as samian ware often was), as wear around the edges was similar to that on the later prehistoric sherds from the same spread.

Sherds of samian ware are the commonest form of Roman pottery in north-east Scotland, although
A

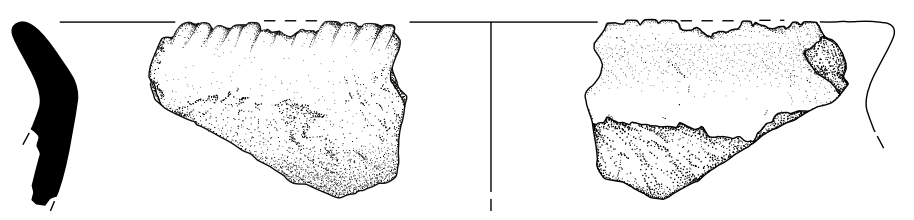

B

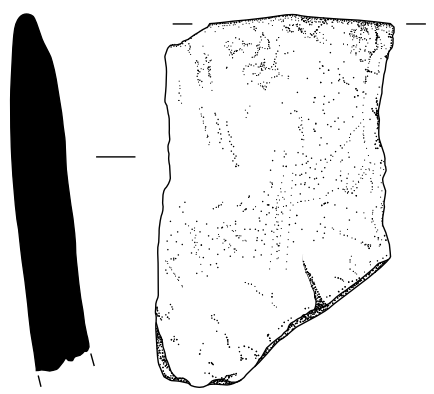

Illus 20 Vessels from Structure 2: A Vessel 7, Ring Ditch 149; B Vessel 16, Post Hole 157 and Deposit 161 

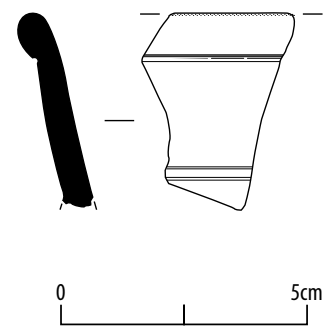

\section{Illus 21 Samian-ware fragment from Deposit} 161 , Structure 2

still rare. Generally, only a single sherd of a vessel is represented. The dominant types are the form 37 deep bowl (as here) and form 31, a shallow bowl. These forms have seen extended recent discussion in the context of finds from Sculptor's Cave, Moray (five sherds, showing clear signs of abrasion for possible pigment; Wallace forthcoming), Deskford, Moray, and Dunnicaer, Aberdeenshire (both single sherds showing no reuse; Wallace 2019 and 2020). In the cases of Sculptor's Cave and Deskford, the contexts suggested these sherds were purposely deposited at ritually significant sites, but at Thainstone it came from a deposit which contained sherds of indigenous pottery in a similar condition, each vessel similarly represented only by a single sherd. The treatment of the exotic samian ware thus mirrors that of the indigenous material.

The date of the samian ware corresponds to the fragment of glass in Pit 100 from the entrance porch of Structure 2, which supports the probability of the structure being of a Middle Iron Age date. Additionally, the similarities in condition of the indigenous pottery from Structure 2 with that of the samian ware could support the fact that the pottery dated as 'late prehistoric' could be Iron Age.

\subsection{Glass}

A small fragment of glass was recovered from Pit 100 in the entrance porch of Structure 2. The colour and quality of the glass were appropriate for a date in the 1 st or 2 nd centuries $\mathrm{AD}$, but the preserved profile could not easily be accommodated within the range of forms commonly made in that colour and which could be expected at that date. The profile had a tight curve, but it was clearly not from an open pushed-in base ring, of the form found on jugs and jars of Isings forms 52, 55 and 67c, and was too large to be the loop from the top of the rim of a collared jar (Isings form 67c) or a tubularrimmed bowl (Isings form 44). The profile would be appropriate for the outer edge of an unguent bottle with a wide discoid reservoir (Isings form 82A2/B2; Price \& Cottam 1998: 175-7) but unfortunately the fragment was too small for a reliable body diameter to be established which would aid in the identification. Such vessels were in use in the 2 nd century, however in comparison to the types of jugs, jars and bowls mentioned above, unguent bottles of any form appear to be very rare amongst the glass types that are occasionally found on native sites in Scotland during the Roman period (Ingemark 2014: 121-2).

\subsection{Cannel coal bangle}

A fragment of a cannel coal bangle (Illus 22) was recovered from a spread of topsoil overlying the infilled souterrain. This is a long-lived style of jewellery, but locally unusual owing to the absence of suitable raw materials in the area. Cannel coal is typically associated with the Coal Measures deposits of central Scotland (Fife being the most northerly), and with a more northern series of workable deposits in Jurassic rocks in eastern Sutherland, around Brora (Gibson 1922: 10-25, 31-6, 43-6; it is not clear if a potential source at Shandwick in Easter Ross is workable). It is thus an exotic raw material for Aberdeenshire, and this is reflected in its rarity in the regional record.

Such finds are all but unknown from later prehistoric and early medieval settlement sites in Aberdeenshire. The only known example is an unfinished bead or ring from the Pictish enclosed site of Maiden Castle, near Bennachie (Cook 2011: 28). It is striking that two other examples were associated with much older ritual or burial monuments, and were likely to relate to later prehistoric veneration or ritual acts at these sites: a bangle fragment from the recumbent stone circle at Old Keig, and a ringpendant in a cache of Roman Iron Age charms inserted into an older burial cairn at Cairnhill, Monquhitter (Childe 1934: 389-90; Stevenson 1967). A related cache may be the hoard from Bruce's Camp, close to Thainstone, which included a series of shale or cannel coal globular gaming 


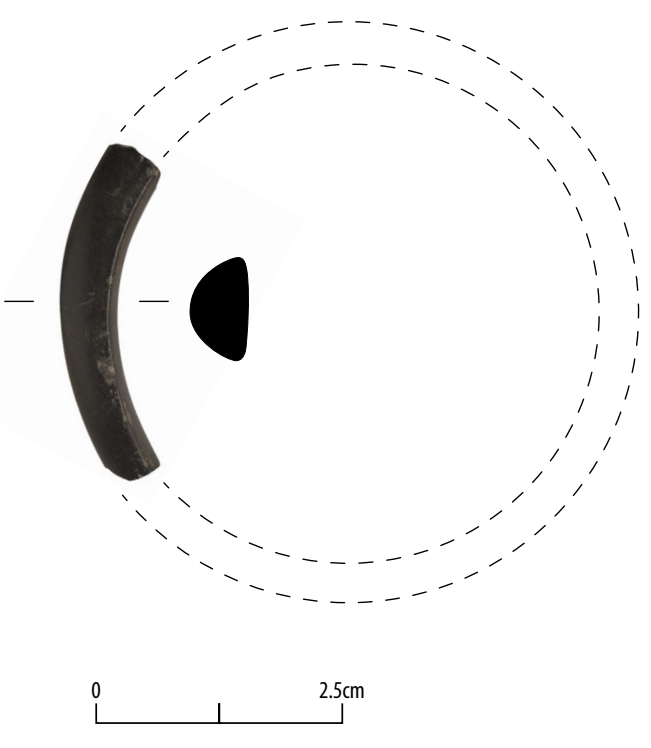

Illus 22 Cannel coal bangle from Deposit 088 overlying the souterrain

pieces of 3rd-6th-century AD date (Callander 1927: 243-6; Ralston \& Inglis 1984: 57; Caldwell et al 2006: 78-9).

Two stray finds add a little to the picture. An intact ring (a stray find from Huntly Castle; NMS X.FN 10) was likely an unusually small ring-pendant, which was an Iron Age type, while an undatable unfinished bead came from West Wrangham, Culsalmond (Aberdeen University Museum, 17493). The southern shore of the Moray Firth shows rather more finds in the later Bronze Age and Iron Age, probably because access to the sources at Brora and Dunrobin was easier. Numbers are small, however, with only a very few finds from any one site (Hunter 2012: 46).

Such black-stone bangles were a long-lived type, and only certain forms have so far proved chronologically diagnostic. Typologically, this example cannot be more tightly dated, and the unsecure context suggested it was not well stratified. We can thus only assume that it ties in to one of the phases of later prehistoric activity on the site. The rarity of such finds in the area would have made it an item of some value, which explains attempts made to repair it after breakage, although their crudity suggests a lack of expertise with the material.

\subsection{Stone tools}

An assemblage of six coarse stone artefacts was recovered, including a stone grinder from the pit group, a hide rubber from Structure 2 and a further four tools associated with the souterrain.

The quartzite grinder in Pit 061 of the pit group (Illus 23) was very heavily used, evident in the wear across almost all its surface, indicating it was a favoured tool, or perhaps a shortage of suitable cobbles nearby. Grinders were a basic form of cobble tool in use throughout prehistory and could have been utilised for a wide range of tasks, such as grinding foods or pigments.

The glossy staining on the schist cobble tool from Ditch 151 in Structure 2 suggested it was used as a hide-rubber, to rub preservatives and/or pigments into hides during the tanning process. Hide-working was likely to have been a common activity on most sites in prehistory but the, often subtle, traces left on hide-working tools mean the craft is probably underrepresented.

Two saddle quern fragments and a rubber were located within Pit 217, immediately to the north of the souterrain, and appeared to form the basis of an external step into the structure. Additionally, a sharpener or work surface was recovered from within the basal fill of the souterrain. The granite saddle querns and quern rubber, from Pit 217, were essential everyday food preparation tools and would have been vital to every prehistoric household (Illus 24). Despite, or perhaps because of, their everyday nature, querns are likely to have been highly valued and their role in structured deposits has seen a great deal of research (eg Brück 2001; Peacock 2013; Watts 2014). The three fragments at Thainstone were all recovered from the lowest of three steps into the souterrain, suggesting they had been reused as paving. Such reuse of querns in structural elements such as paving, walls or post-hole packing has been noted throughout the history of their use (Peacock 2013: 173) and may have been a form of foundation deposit in hope of an auspicious beginning to a new structure.

The quern forms are not chronologically distinct, but their deposition seems likely to correspond with the souterrain's construction. Querns have been recovered from similar structured deposits on other later prehistoric sites in north-east Scotland, such as 


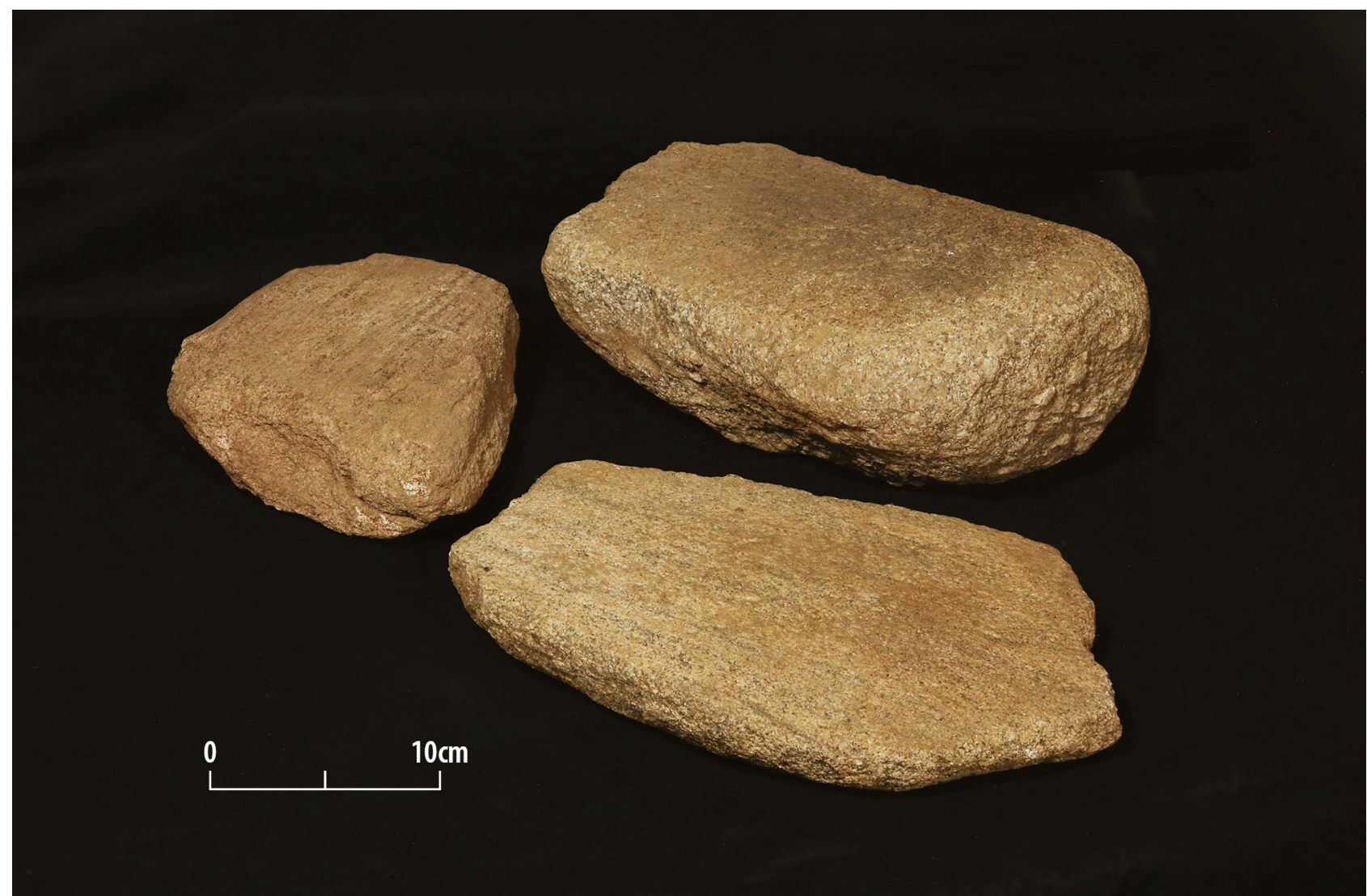

Illus 23 Stone grinder, Pit 061

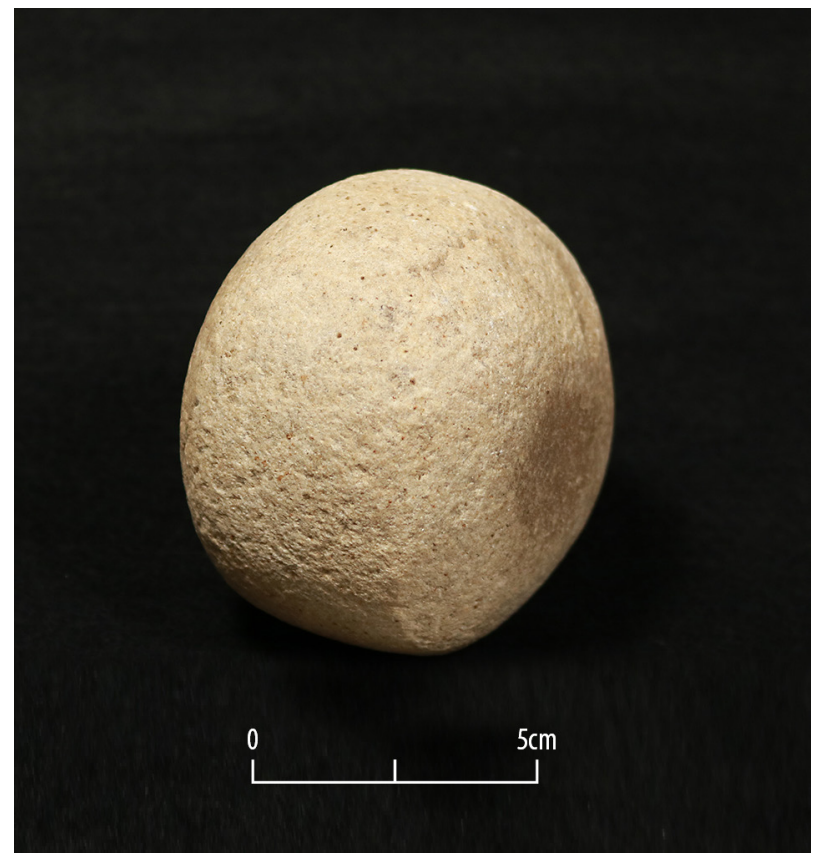

Illus 24 Quern stones and rubber, Pit 217, step into the souterrain

saddle quern fragments in paving of a souterrain-like feature at Stracathro, Angus (Cruickshanks 2018), rotary querns placed in the paving of Ardestie and Carlungie souterrains in Angus (Wainwright 1963: 132-4, 144-5) and saddle querns in various structural elements of the roundhouses at Kintore, Aberdeenshire (Engl 2008: 221-5), illustrating how long-lived and widespread this tradition was.

The schist fragment of sharpener or work surface from the basal fill of the souterrain had linear grooves, suggesting that it had been used for sharpening or shaping bone or metal points/pins. The function of the object was difficult to confirm based on the small size of the fragment.

\subsection{Ironworking}

A total of $514 \mathrm{~g}$ vitrified material was recovered during excavation and sample processing. Most of the material recovered was diagnostic of ironworking, including both smelting and blacksmithing. Smelting slag was recovered from an isolated pit, while very small quantities of residual hammerscale from blacksmithing were dispersed in contexts across the site. It is therefore unclear when the blacksmithing activity dates from.

The isolated pit (Pit 205, Illus 2) was $c 35 \mathrm{~m}$ north-east of Structure 2. The unabraded nature of 
the smelting slag recovered from this feature strongly suggested this was an in situ deposit or primary dump with little disturbance since deposition. The pit's dimensions (approximately $0.4 \mathrm{~m}$ in diameter) were consistent in size with local Iron Age furnaces (Cruickshanks 2017), suggesting it may have been the plough-truncated base of an iron smelting furnace. However, no fired clay lining was present. A primary dump was therefore more likely, which suggests a smelting furnace was in operation nearby. The pit was undated, and iron slag is rarely chronologically distinct, since the process changed little from the Early Iron Age to the post-medieval period in many rural areas. However, the proximity of this feature to an Iron Age roundhouse and souterrain adds weight to the ironworking activity also being Iron Age, as ironworking evidence in north-east Scotland is almost exclusively found on open roundhouse settlements (Cruickshanks 2 017).

Very small quantities of hammerscale and slag spheres were recovered from various features across the site, including from Post Hole 120 in Structure 2. These micro-debris form when hot flakes and droplets of slag fly from iron as it is hammered, and in larger quantities can reveal the position of a blacksmith's hearth and anvil. The quantities here were too small and were more likely to have become dispersed across the site over time, making it difficult to now know exactly when or where the blacksmithing was taking place.

Based on current evidence, the Moray Firth saw the most intensive ironworking activity in Scotland during the Iron Age, with several sites, such as Culduthel, Birnie and Clarkly Hill (Hatherley \& Murray 2020; Hunter in prep a; b), producing multiple furnaces and huge dumps of slag. Not all sites in the area were producing on a large scale though, with several, like Thainstone, providing evidence of small-scale or even singleevent ironworking. Iron Age ironworking sites are currently scarcer in Aberdeenshire than around Moray and Inverness, therefore this site is potentially an important addition to our understanding of ironworking on the fringes of the main production region.

\subsection{Charcoal}

Charcoal fragments of birch, oak and hazel were recovered from within Vessel 3 of Cremation Pit 097. These fragments were possibly from the pyre and the fuel used in the cremation, and would have been collected with the cremated skeleton. Charcoal analysis on material from a variety of Bronze Age cremation burials have indicated that certain tree taxa, primarily oak, were preferentially selected for inclusion in cremation contexts across Britain and Ireland, but that these patterns in fuel selection did vary across regions (O'Donnell 2016). Oak has been identified as the abundant taxon in cremation samples at many sites in Scotland, including Ness Gap, Fortrose (Woodley et al 2020) and Skilmafilly, near Maud, Aberdeenshire (Cressey 2012). The Skilmafilly charcoal assemblage bears some similarity to that of Thainstone, consisting of oak, birch, hazel and alder, though at Skilmafilly alder was present in only trace amounts. A further assemblage from Nether Beanshill to the north-east of Milltimber, Aberdeenshire (Dingwall et al 2019) also comprised alder and hazel branches and twigs, but with only occasional oak fragments present.

Oak and birch were also recovered from Feature 017. The oak charcoal was from heavily fragmented 'blocks', which suggested that it derived from a mature tree. This was further supported by the lack of curvature in the rings of the transverse surfaces, indicating that it was from the trunk or a major branch. The birch charcoal was heavily fragmented, and it was often not possible to determine the diameter of the wood. Nor was it possible to ascertain whether the birch was structural pyre material or fuel. While it is possible this material derives from a domestic hearth, the types present mirror the findings of the urned cremations and thus may derive from funeral pyre rakings.

Oak, alder, birch and hazel are all species that are native to north-east Scotland (Cressey 2012) and were commonly available in Bronze Age Scotland (Tipping 2003). The reason for the association of oak with Bronze Age cremations is unclear. One hypothesis is that due to the strength of oak wood it was used for spars to support a body (Cressey 2012). The tree species in the Thainstone cremations, and in other nearby contemporary cremation deposits, would all have been locally available and therefore 
provided a ready supply of fuel and timber for domestic and funerary activities.

Charcoal from the souterrain was recovered from two fills from within the structure. Samples from the basal fill comprised birch (Betula sp.), roundwood fragments, with smaller amounts of heavily fragmented oak (Quercus sp.), willow (Salix sp.) and hazel (Corylus avellana). Charcoal from a later deposit was very similar in nature, with an abundance of birch and small numbers of heavily fragmented hazel and smaller numbers of oak. Most of the non-oak charcoal was of fragmented roundwood and the birch charcoal appeared to derive from small $(10-20 \mathrm{~mm})$ diameter branches. It was not possible to establish the diameter of the hazel and willow due to its naturally fragmented nature. Birch, hazel and willow roundwood would have been ideal for wickerwork panels and stakes due to their pliable nature. The oak fragments appeared to derive from trunk wood. Willow, birch and hazel roundwood fragments were also present in a charcoal-rich spread (182) located on the northern side of the souterrain. This deposit was not radiocarbon-dated but was assumed to be contemporary with the occupation and use of Structure 2 and the souterrain. The birch and willow derived from small-diameter $(10-20 \mathrm{~mm})$ roundwood branches, and the hazel from slightly smaller branches $(10-15 \mathrm{~mm})$. With the addition of willow, the taxonomy of the charcoal identified in the souterrain and Spread 182 was similar to that of the cremation pits, suggesting these species were still locally available in the Iron Age. The small-diameter birch, hazel and willow roundwood would have been ideal for wickerwork panels and stakes, which may have been used in addition to the stone lining of the souterrain at Thainstone. The function of the carbonised wood from the souterrain is difficult to determine, and whilst it is possible that the wood comprised internal structural elements (walling, roofing or flooring), the versatility of these wood taxa means they could have served as many other artefacts such as baskets, poles or fuel.

\subsection{Other plant remains}

A moderate number of cereal grains were recovered from features across the site. The grains exhibited mixed levels of preservation ranging from moderate to poor. Sixteen abraded cereal grains were present in the upper fill of Feature 017 but were likely to have been intrusive rather than deliberately deposited. Hulled barley (Hordeum vulgare) was the most-encountered cereal and most abundant in Ditches 151 and 149 in Structure 2, and in the fill of the souterrain. The small assemblage offers some information on site economy. Hulled barley appeared to be the dominant grain throughout, suggesting that it must have been the main cultivar in the area and that some crop-processing was being carried out on-site. One of the many hypotheses regarding the use of souterrains is for the storage of agricultural produce (Dunwell \& Ralston 2008). However, given the relatively small number of grains recovered from the souterrain, and their poor condition, it is likely that they had undergone some movement prior to burial. Therefore, it is more likely that the barley was incidentally incorporated into the souterrain rather than stored there.

Hazel nutshell (Corylus avellana) was present in small amounts (generally $<0.1 \mathrm{~g}$ ) in eight features. The largest amount of nutshell (1g) was present in Ditch 187 from Structure 1. Hazelnuts were a common resource which were exploited during the Bronze Age and Iron Age (Bishop 2019).

A small number of weed seeds, such as common nettle (Urtica dioica) were recovered from Feature 017 and Pit 091 of the pit group. Charred weed seeds were also recovered from a small number of settlement-related features and comprised seeds of grasses (Poaceae), peas/vetches (Lathyrus/Vicia), seeds of the knotweed family (Polygonaceae), chickweed (Stellaria media) and brambles (Rubus fruticosus). The presence of these seeds further suggests the exploitation of local wild resources. 